\section{PA-560, a Southern Root-knot Nematode-resistant, Yellow-fruited, Habanero-type Pepper}

\author{
Richard L. Fery ${ }^{1}$ and Judy A. Thies \\ U.S. Department of Agriculture, Agricultural Research Service, U.S. Vegetable \\ Laboratory, 2700 Savannah Highway, Charleston, SC 29414-5334
}

Additional index words. Capsicum chinense, Meloidogyne incognita, vegetable breeding

PA-560 is a new Habanero-type pepper (Capsicum chinense Jacq.) released 20 Oct. 2009 by the Agricultural Research Service of the U.S. Department of Agriculture (USDA). PA-560 is a yellow-fruited, Habanero-type advanced breeding line that is homozygous for a dominant gene conditioning a high level of resistance to the southern root-knot nematode [Meloidogyne incognita (Chitwood) Kofoid and White]. The southern root-knot nematode is a major pest of peppers in the United States, and all Habanero-type cultivars currently popular with commercial growers and home gardeners are susceptible (Fery and Thies, 1997). The release of PA-560 will provide pepper breeders interested in developing yellow-fruited cultivars of Habanero-type peppers access to a near-cultivar quality parental line that is homozygous for the southern rootknot nematode resistance gene.

\section{Origin}

In 1995, recurrent backcross breeding procedures were initiated to transfer the dominant southern root-knot nematode resistance gene from a Scotch Bonnet accession into classical Habanero-type backgrounds (Fig. 1). The donor parent was PA-426 and the recurrent parent was PA-350. PA-426 is a southern root-knot nematode-resistant, Scotch Bonnet-type germplasm line that was released by the USDA in 1997 (Fery and Thies, 1997, 1998a, 1998b). PA-350, susceptible to southern root-knot nematodes, is a classical, Habanero-type cultigen obtained from an heirloom collector. In 2002, a total of $63 \mathrm{BC} 4 \mathrm{~F} 3$ populations were evaluated in a greenhouse test for reaction to $M$. incognita and in a replicated field test for horticultural characteristics. Although superior, southern root-knot nematode-resistant, orange-fruited $\mathrm{BC} 4 \mathrm{~F} 3$ populations were identified in these 2002 tests, no resistant, yellow-

Received for publication 24 Sept. 2010. Accepted for publication 11 Mar. 2011.

We acknowledge Dr. Paul W. Bosland, Department of Plant \& Environmental Sciences, New Mexico State University, Las Cruces, NM, for assistance in obtaining the pungency determination. The technical assistance of Floyd P. Maguire and Sharon Buckner, ARS-USDA, is also gratefully acknowledged.

${ }^{1}$ To whom reprint requests should be addressed; e-mail Richard.Fery@ars.usda.gov. fruited $\mathrm{BC} 4 \mathrm{~F} 3$ populations were found. However, one of the susceptible yellow-fruited BC4F3 populations (02-564) did exhibit superior horticultural characteristics, and a single plant from this population was subsequently crossed with a single plant from one of the resistant, orange-fruited $\mathrm{BC} 4 \mathrm{~F} 3$ populations (02-531) to initiate a pedigree breeding procedure to develop a southern root-knot nematode-resistant, yellow-fruited, Habanerotype line. PA-560 was derived from a single F3 $($ BC4F3 $\times$ BC4F3) plant grown in 2005 . Both of the parental lines used in the last cross are sib lines of the orange-fruited, southern rootknot nematode-resistant cultivar TigerPaw-NR that was released by the USDA in 2006 (Fery and Thies, 2007).

\section{Description}

PA-560 has a compact plant habit (height $=$ $83 \mathrm{~cm}$; width $=103 \mathrm{~cm}$ ) and produces campanulate (a flattened bell or lantern-type shape), yellow-colored fruit (Fig. 2). PA-560 fruit have a more elongate shape than those of 'TigerPawNR'. The period from transplanting to first harvest of mature fruit is 77 to $86 \mathrm{~d}$ at Charleston, SC (Tables 1 and 2). There are typically three pedicels per axil and the pedicel breeding line PA-560. position at anthesis is intermediate. Flower petal color is white; the corolla throat markings are yellow, and the stamens have white filaments and purple anthers. At full anthesis, the length of the style is the same or slightly greater than the length of the stamen. The leaves are large, lanceolate-shaped, and have an intermediate green color. The stem pubescence is sparse and the leaves are glabrous. Fruit-bearing plants exhibit extensive anthocyanin pigmentation on the stems, branches, and petioles; there is moderate pigmentation at the base of the pedicels. The seedling hypocotyl exhibits heavy anthocyanin pigmentation. The fruits are attached to the pedicel in a pendant manner (typically two fruit per cluster); the calyx is saucer-shaped (flat, does not envelop the fruit base); the calyx margin shape is dentate; the annular constriction at the junction of the calyx and pedicel is present; and the pedicels are short, curved, and slender. The fruits are non-deciduous, i.e., the pedicel and calyx usually remain on the fruit at harvest.

The results of two replicated field studies conducted at Charleston, $\mathrm{SC}$, indicate the yield potential of PA-560 is comparable to that of traditional Habanero-type cultigens. In a 2006 field test, no difference in marketable fruit yield could be demonstrated between PA-560 and the recurrent Habanero-type parent PA350 (PA-560: 17,313 kg.ha-1 ${ }^{-1}$ PA-350: 17,313 $\left.\mathrm{kg} \cdot \mathrm{ha}^{-1}\right)$. In a 2007 field test, no difference in marketable fruit yield could be demonstrated between PA-560 and the commercial cultivar Habanero (PA-560: $6409 \mathrm{~kg} \cdot \mathrm{ha}^{-1}$; Habanero: $\left.6929 \mathrm{~kg} \cdot \mathrm{ha}^{-1}\right)$.

A typical PA-560 fruit weighs $\approx 7.6$ to $8.0 \mathrm{~g}$. The shape of the pedicel attachment end of the fruit is truncate, the neck at the base of the fruit is absent, and the shape at the blossom end of the fruit is pointed. The cross-section of a typical fruit at the level of the placenta exhibits a slightly corrugated shape; the longitudinal cross-section exhibits a narrow triangular to

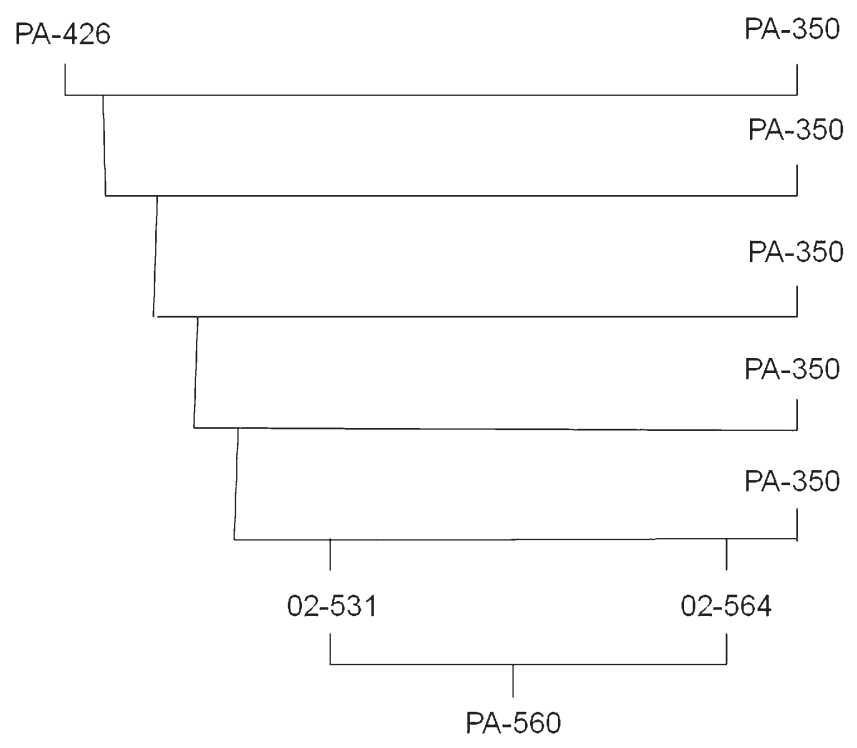

Fig. 1. Pedigree of the yellow-fruited, southern root-knot nematode-resistant, Habanero-type pepper 


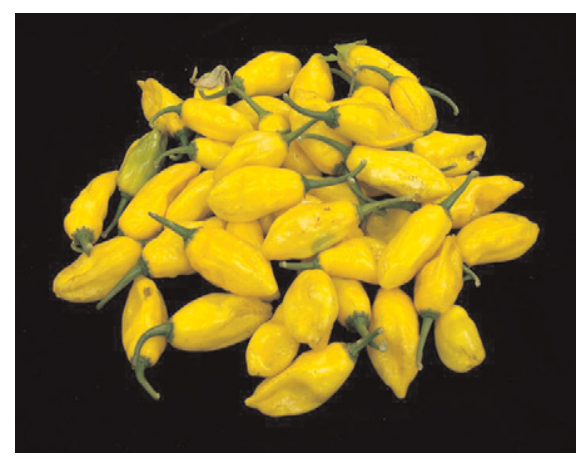

Fig. 2. Freshly-harvested fruit of the southern rootknot nematode-resistant, yellow-fruited, Habanerotype pepper breeding line PA-560.

Table 1. Days from transplanting to harvest, fruit size, and marketable fruit yield for the southern root-knot nematode-resistant, yellow-fruited breeding line PA-560 and the southern root-knot nematode susceptible, orange-fruited, Habanerotype recurrent parent PA-350 in a field trial grown at Charleston, SC, $2006 .^{\mathrm{z}}$

\begin{tabular}{lccc}
\hline $\begin{array}{l}\text { Pepper } \\
\text { accession }\end{array}$ & $\begin{array}{c}\text { Days to } \\
\text { harvest } \\
\text { (no.) }\end{array}$ & $\begin{array}{c}\text { Fruit } \\
\text { size } \\
\text { (g/fruit) }\end{array}$ & $\begin{array}{c}\text { Marketable } \\
\text { fruit yield } \\
\left(\mathrm{kg} \cdot \mathrm{ha}^{-1} \text { ) }\right.\end{array}$ \\
\hline PA-560 & $77.0^{\mathrm{y}}$ & $8.0 \mathrm{a}^{\mathrm{x}}$ & $17,313 \mathrm{a}$ \\
PA-350 & 77.0 & $8.4 \mathrm{a}$ & $18,460 \mathrm{a}$ \\
\hline
\end{tabular}

zThe experimental design was a randomized complete block with three replications. Single-row plots were used (10 plants per plot, $30 \mathrm{~cm}$ between plants, and $102 \mathrm{~cm}$ between rows). The trial was established using transplants; the trial was planted on 4 May 2006 and fully mature fruits were harvested from 20 July 2006 to 28 Aug. 2006 (six harvests).

${ }^{\mathrm{y}}$ First harvest for all plots made on 20 July 2006.

${ }^{\mathrm{x}}$ Mean separation within columns by Student-

Newman-Keuls multiple range test $(P \leq 0.05)$.

trapezoid shape. A typical PA-560 fruit is 3.37 $\mathrm{cm}$ wide $\times 4.43 \mathrm{~cm}$ long and has a thin wall $(1.43 \mathrm{~mm})$ (Table 3$)$. The color of immature fruit is a glossy, dark green; the color of harvest-stage fruits is a glossy, bright yellow (Munsell color rating: 3.8 Y 6.8/10.5). The fruits are extremely pungent (326,710 Scoville heat units), and a typical fruit has three locules (average number of locules: 3.3).

PA-560 is homozygous for a dominant gene that conditions a high level of resistance to southern root-knot nematodes. It exhibited a high level of resistance to the southern root-knot nematode in a 2006-2007 winter greenhouse test; no galls or egg masses were evident on any of the root systems (Table 4). The resistance exhibited by PA- 560 is equal to that exhibited by
Table 2. Days from transplanting to harvest, fruit size, and marketable fruit yield for the southern root-knot nematode-resistant, yellow-fruited, Habanero-type pepper breeding line PA-560 and the southern root-knot nematode-susceptible, orange-fruited cultivar Habanero in a field trial grown at Charleston, SC, 2007. ${ }^{\mathrm{s}}$

\begin{tabular}{lccc}
\hline $\begin{array}{l}\text { Pepper } \\
\text { accession }\end{array}$ & $\begin{array}{c}\text { Days to } \\
\text { harvest } \\
\text { (no.) }\end{array}$ & $\begin{array}{c}\text { Fruit size } \\
(\mathrm{g} / \text { fruit })\end{array}$ & $\begin{array}{c}\text { Marketable } \\
\text { fruit yield } \\
\left(\mathrm{kg} \cdot \mathrm{ha}^{-1}\right)\end{array}$ \\
\hline PA-560 & $86.0^{\mathrm{y}}$ & $7.6 \mathrm{a}^{\mathrm{x}}$ & $6409 \mathrm{a}$ \\
Habanero $^{\mathrm{w}}$ & 86.0 & $8.3 \mathrm{a}$ & $6929 \mathrm{a}$ \\
\hline
\end{tabular}

${ }^{\mathrm{z}}$ The experimental design was a randomized complete block with three replications. Single-row plots were used ( 10 plants per plot, $30 \mathrm{~cm}$ between plants, and $102 \mathrm{~cm}$ between rows). The trial was established using transplants; the trial was planted on 24 Apr. 2007 and fully mature fruits were harvested from 19 July 2007 to 27 Aug. 2007 (seven harvests). ${ }^{y}$ First harvest for all plots made on 19 July 2007.

${ }^{x}$ Mean separation within columns by StudentNewman-Keuls multiple range test $(P \leq 0.05)$.

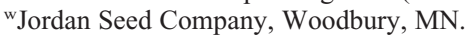

Table 3. Comparison of fruit characteristics of the southern root-knot nematode-resistant, yellowfruited, Habanero-type pepper breeding line PA-560 and the southern root-knot nematodesusceptible, orange-fruited cultivar Habanero in a field trial grown at Charleston, SC, 2007.

\begin{tabular}{lcccc}
\hline & \multicolumn{4}{c}{ Fruit characteristic } \\
\cline { 2 - 5 } Pepper & $\begin{array}{c}\text { Width } \\
\text { accession }\end{array}$ & $\begin{array}{c}\text { Length } \\
(\mathrm{cm})\end{array}$ & $\begin{array}{c}\text { Wall } \\
\text { thickness } \\
(\mathrm{cmm})\end{array}$ & $\begin{array}{c}\text { Locules } \\
(\text { no. })\end{array}$ \\
\hline PA-560 $^{2.37 \mathrm{a}^{\mathrm{y}}}$ & $4.43 \mathrm{a}$ & $1.43 \mathrm{~b}$ & $3.3 \mathrm{a}$ \\
Habanero $^{\mathrm{x}}$ & $2.40 \mathrm{a}$ & $4.37 \mathrm{a}$ & $1.70 \mathrm{a}$ & $3.6 \mathrm{a}$ \\
\hline
\end{tabular}

${ }^{\text {zThe experimental design was a randomized complete }}$ block with three replications (10 typical fruit were sampled from each plot).

${ }^{\mathrm{y}}$ Mean separation within columns by StudentNewman-Keuls multiple range test $(P \leq 0.05)$.

xJordan Seed Company, Woodbury, MN.

the donor of the resistance gene, the Scotch Bonnet-type germplasm line PA-426.

The southern root-knot nematode-resistant PA-560 is recommended for use as a parental line by pepper breeders interested in developing yellow-fruited, southern root-knot nematoderesistant cultivars of Habanero-type peppers. The dominant nature of the gene conditioning the southern root-knot nematode resistance trait would make PA-560 useful as an inbred parent for development of southern root-knot nematoderesistant F1 hybrids.

\section{Availability}

Small trial samples of PA-560 breeder's seed are available for distribution to all
Table 4. Average root-gall index and average egg mass index for PA-560, PA-350 (susceptible recurrent parent), and PA-426 (resistant donor parent) grown in soil infested with the southern root-knot nematode, Meloidogyne incognita race 3 (Greenhouse Experiment, 2006-2007). ${ }^{\mathrm{z}}$

\begin{tabular}{lcc}
\hline Accession & Gall index $^{\mathrm{y}}$ & Egg mass index \\
\hline PA-560 & $1.00 \pm 0.00^{\mathrm{w}}$ & $1.00 \pm 0.00$ \\
PA-350 & $2.85 \pm 0.07$ & $2.85 \pm 0.07$ \\
PA-426 & $1.00 \pm 0.00$ & $1.00 \pm 0.00$ \\
\hline
\end{tabular}

${ }^{\mathrm{z} U n r e p l i c a t e d ~ e x p e r i m e n t ~(20 ~ p l a n t s ~ p e r ~ a c c e s s i o n ; ~}$ seeds planted on 27 Nov. 2006 and seedlings subsequently transplanted into a steam-pasteurized mixture of soil, sand, and peat; soil surrounding roots of each seedling was infested with $3000 \mathrm{M}$. incognita race 3 eggs on 3 Jan. 2007; and roots of all plants removed from the growth media on 5 Mar. 2007 for evaluation for galling and egg masses).

${ }^{\mathrm{y}}$ Rated on a scale of 1 to $5: 1=$ no galls; $2=$ light galling, $1 \%$ to $25 \%$ of root system galled; $3=$ moderate galling, $26 \%$ to $50 \%$ of root system galled; $4=$ heavy galling, $51 \%$ to $80 \%$ of root system galled; and $5=$ severe galling, $81 \%$ to $100 \%$ of root system galled.

${ }^{x}$ Rated on a scale of 1 to 5: 1 = no egg masses evident, $2=$ scattered egg masses covering $1 \%$ to $25 \%$ of root system, $3=$ moderate number of egg masses covering $26 \%$ to $50 \%$ of root system, $4=$ numerous egg masses covering $51 \%$ to $80 \%$ of root system, and $5=$ extremely large number of egg masses covering $81 \%$ to $100 \%$ of root system.

${ }^{\mathrm{w}} \pm \mathrm{SE}$.

interested research personnel. Genetic material of this release will be deposited in the National Plant Germplasm System where it will be available for research purposes, including the development and commercialization of new cultivars. It is requested that appropriate recognition of source be given when this germplasm contributes to research or development of a new breeding line or cultivar.

\section{Literature Cited}

Fery, R.L. and J.A. Thies. 1997. Evaluation of Capsicum chinense Jacq. cultigens for resistance to the southern root-knot nematode. HortScience 32:923-926.

Fery, R.L. and J.A. Thies. 1998a. Genetic analysis of resistance to the southern root-knot nematode in Capsicum chinense Jacq. J. Amer. Soc. Hort. Sci. 123:1008-1011.

Fery, R.L. and J.A. Thies. 1998b. PA-353, PA398, and PA-426: Southern root-knot nematoderesistant Capsicum chinense Jacq. germplasm lines. HortScience 33:760-761.

Fery, R.L. and J.A. Thies. 2007. 'TigerPaw-NR', a root-knot nematode-resistant, Habanero-type pepper. HortScience 42:1721-1722. 